\title{
How Practices of Managing Partnerships Contributes to the Value Creation-Public-Social Partnership Perspective
}

\author{
Aldona Frączkiewicz-Wronka ${ }^{1}$ and Martyna Wronka-Pośpiech ${ }^{2, *(1)}$ \\ 1 Department of Public Management and Social Science, University of Economics Katowice, 40-287 Katowice, \\ Poland; aldona.fraczkiewicz-wronka@ue.katowice.pl \\ 2 Department of Entrepreneurship and Management Innovation, University of Economics Katowice, \\ 40-287 Katowice, Poland \\ * Correspondence: martyna.wronka-pospiech@ue.katowice.pl
}

Received: 22 October 2018; Accepted: 13 December 2018; Published: 17 December 2018

\begin{abstract}
In this paper, the authors aim to answer the question of which model of public management-Public Administration, New Public Management, or Collaborative Public Management-is conducive to achieving better results in the public-social partnership. We understand public-social partnership as an activity undertaken in collaboration between organizations operating both in the public and social sectors. We also claim that Collaborative Public Management fosters sustainability in partnerships and should therefore be preferred in partnerships that are focused on delivering social services. In particular, we aim to find out how management practices that are used in the public-social partnership contribute to the co-creation of public value. The article brings together theoretical insights and empirical data. First, we integrate insights from different strands of literature. Next, empirical data are derived from two main sources: first, a specific case of the public-social partnership established by 18 institutions and organisations, followed by quantitative research that was conducted in 173 partnerships in Poland. Based on the presented case study, analysis of the survey results and in-depth interviews (IDIs) conducted with the 18 leaders of the organisations constituting the partnership, the observed pattern revealed the dominance of the Collaborative Public Management model contributing to the success of the partnership. It was also identified what actions were taken by the manager of the partnership in order to maintain links between the partners, build trust, and win their support and legitimisation in public space-all of which are necessary to create public value, which in turn contributes to the sustainability of the partnership.
\end{abstract}

Keywords: public management; public-social partnership; public value; co-innovation; sustainability

\section{Introduction}

Nowadays we can observe a gradual departure from the state monopoly in the public sector, and moving towards the search for effective solutions of delivering social services to citizens on the basis of organising the public sector in such a way that it will foster the creation of quasi-market systems and forms of networking. This means shifting research attention from individual organisations to emerging systems, which might be characterised as multi-stakeholder collaboration, such as a public-social partnership. Furthermore, multi-stakeholder collaboration is as an interesting research avenue, as in practice it fosters better results achieved by entities that are engaged in social services delivery and it is conducive to attaining cohesion, competitiveness, and sustainability. The importance of partnerships in general applies both to theory and practice of public management due to European Union (EU) directives promoting social innovation as an organisational concept of public service 
delivery. However, this kind of collaboration is successful only when the partnership is correctly designed and managed, resources of organisations constituting the partnership are complementary and the logic behind how individual organisations and their leaders operate is in line with the needs of the local community.

Organisations demand a creative network and relationships to enable innovation, which also refers to public organisations. That is why notions such as 'co-creation' and 'co-innovation' often appear in the context of innovation activity in the public sector. The core of co-innovation includes engagement, co-creation, and compelling experience for value creation. Following this thought, the paper defines partnership as a social innovation, while co-innovation as a way partnership is managed by various partners, so it can achieve public value being the main goal of its existence. One of the most important factors that improve the efficiency of social services delivery are managerial practices [1]. Organisational reality tends to confirm the observation that an important factor determining the effective use of available resources is the ability of leaders to use appropriate managerial practices allowing them to succeed in their activities. Therefore, not focusing on one management model but rather combing practices creating the desired value for the local community.

Adding to the above considerations, this paper aims to answer the question of which model of public management-Public Administration, New Public Management, or Collaborative Public Management-is conducive to achieving better results in the public-social partnership. Therefore, which of them contributes most to the fact that objectives of the partnership, being a desired public value, are achieved and, in turn, encourages its sustainability. We combine novel theoretical insights with empirical data from Poland. The structure of the paper is as follows. After an introduction, we present a discussion of the underlying theoretical assumptions about collaborative innovation, value creation in public and social services, and partnerships. Second, the research design is discussed. Research results are presented in the fourth section, while the last part of the paper summarises theoretical and practical contributions, addresses research limitations, and points to future research directions.

\section{Theoretical Background}

\subsection{Collaborative Innovation as an Emerging Concept to Co-creation a Value}

From the beginning of 21st century, significant changes have been observed regarding the provision of social services [2-8]. These changes manifests itself in three dimensions that are associated with a new-social-aspect of (self)organisation, being:

1. forms of cooperation between people-as everyone is able to change rules of the game and have an impact on the surrounding reality (irrespective of individual authority or significance);

2. the emergence of the collaborative economy and/or collaborative network built upon dispersed networks connecting individuals, groups, or communities-these collaborative networks are co-created by the community of people sharing similar needs or interests and involve the maximum use of available resources and potential for collaboration; and,

3. the revival of neighbourly and community life allowing the creation of one's own identity facilitated and confirmed through social ties [9].

The above-mentioned social phenomena, together with such developments as crowdfunding, crowdsourcing, the concept of shared value, and the shift from value chains to value flows, are superimposed on the traditional community mechanisms (local communities and categorical communities), which are also undergoing a significant evolution [10]. Moreover, the difference between the producer and the consumer is blurring as users become co-creators and the idea of co-creation goes far beyond the idea of user involvement. Now, it is more about transferring the responsibility and resources from professionals to users as well as about involving people in designing and executing services for themselves. It is connected with the belief that both individual and collective 
satisfaction is best achieved through mutual assistance. Therefore, the subject of innovation attracts the attention of a wide spectrum of both individual and organisational actors, representing the world of science and business.

Co-innovation (short for collaborative innovation) relates to the innovation processes that systematically integrate the users' knowledge and experiences to ensure that innovation creates substantial value [11]. Depending on the perspective, co-innovation can be understood quite narrowly - as one of the options of the development strategy of modern organisations [12], more widely as a new concept in the field of innovation management [13], or, finally, as a new paradigm in the approach to innovation and innovation management [14-16]. It requires collaboration among various organisations, actors, levels, or segments [17]. As Romero and Molina [18] suggest, co-innovation provides a competitive advantage by combining the best skills or core competencies and resources of two or more organisations, as well as end-user knowledge of a product or a service to co-create or co-produce a value proposition that is more compelling and relevant to the consumers' needs and expectations. Beelaerts van Blokland et al. [16] understand co-innovation as the creation of a partnership between companies and/or institutes and/or customers on sharing knowledge, costs, and benefits in order to create unique value for the customer. The limitation of this definition lays in the fact that it narrows the audience (end-users) of newly created value to customers only. Additionally, it refers to the concept of value co-creation focusing on increasing value for the customer [19], while recent literature on the topic has identified the need for a multi-stakeholder perspective on value co-creation processes, the effect of which should be increasing the value for all (or almost all) involved and/or interested parties [20]. According to Bonney et al. [13], co-innovation is the situation when two or more companies in the value chain collaborate to innovate in product, process, raw material inputs, markets, or governance to improve the efficiency and/or effectiveness of delivering value to consumers and overall sustainable competitive advantage of the whole chain. This approach indicates the need to focus on creating value for the customer, but it also emphasizes the orientation of the organisation towards creating competitive advantage, as suggested also by Romero and Molina [18]. However, it limits collaboration processes to inter-organisational collaboration, thus excluding collaboration with individual stakeholders, such as customers, communities of interest. or affinity groups. The broadest definition defines co-innovation as an approach that is based on the on-going and continuous use of internal, external, collaborative, and co-creative ideas that can be converged to create organisational and shared value [14] (p. 818). It can also be understood as a platform where new ideas or approaches from various internal and external sources are applied differently to create new value or experience for all stakeholders, including consumers [21]. Both definitions indicate the involvement of different external actors along with resources at their disposal. Besides, the definitions refer to the joint creation of innovation under the assumption of creating value for all participating stakeholders (i.e., suppliers, partner organizations, outside collaborators, customers, and the general public at large) and for the organisation itself.

In order to fully understand the concept of co-innovation, it is necessary to define the external actors participating in the joint creation of innovation and the process of value co-creation. Two approaches regarding this area can be identified in the subject literature. The narrow approach takes into account only one type of external entities, i.e., other organisations [12,22] or customers [23,24]. The other approach, so called 'horizontal co-innovation', takes into account various types of wide external partners, such as competitors, non-competitors, institutions and research institutions, universities, and customers $[13,15,25]$, but also other potential stakeholders, even if they are not directly associated with the product supplied by the organisation to the market [26]. To date, much has already been written on co-innovation in the private sector. Therefore, it is no surprise that the topic attracts attention of researchers interested in the public sector, especially because nowadays the role of government and its entities is not only to ensure stability, resilience, and continuity, but also to embrace a strategic and systematic effort to manage emergence and create positive change [27]. 


\subsection{Value Creation in Social Services Delivery}

Public sector innovation stems from the need of governments to increase and enhance the responsiveness of the provided services with the purpose of sufficiently meeting the needs of end-users, both individual and collective. This involves improving services, reaching out to public expectations, containing costs, and improving efficiency levels, leveraging the potential of information and communication technologies [28,29]. The need for governments to become more open, accessible, responsive, collaborative, and demand-oriented is reflected in the recent European Commission report, according to which the innovation paradigm in the public sector should be based on four principles:

1. co-design and co-creation (with other parts of government, businesses, the non-profit sector and citizens),

2. adopting new and collaborative service delivery models,

3. embracing creative disruption from technology (social media, big data), and

4. adopting an attitude of experimentation and entrepreneurship [30].

In order to fulfil these principles, especially the first two of them, it is crucial for public sector organisations to learn how to collaborate actively with other public sector entities, the non-profit sector, business entities, and citizens themselves.

As it has already been mentioned, value co-creation is characterised as a process by which the resources of at least two organisations are combined in order to achieve goals that the parties would not be able to achieve individually [31]. Clearly, the goals of public sector organisations vary from those in the private sector, as they are driven by the objective of creating public value instead of creating private value [32]. Although public sector value is much more difficult to explain, Moore defines it as the equivalent of shareholder value or private value and highlights that public organisations aim at delivering not only value for individuals, but also value for people as citizens as a collective [32]. As traditional incremental innovation forms might be no longer appropriate, since they do not take into full account the relationships between organisations that are involved in the provision of complex services [33] (p. 2), a public sector entity opens its value chain to the stakeholders whom it serves. Stakeholders organised in communities of interest insert themselves into the public service value chain and become active participants in it. In effect, public sector employees and stakeholders, such as citizens, basically co-create the public sector value proposition [34] (p. 42). In that sense, co-innovation concept-especially in the aspects that are associated with the production and delivery of social service-is often used in relation to value creation in the public sector [35,36]. As Virtanen and Stenvall [37] (p. 102) notice, social services are not only provided by the public authorities, represented by public officials and legitimised by politicians, and ultimately by voters. They are also spaces for interaction, collaboration, co-operation, and co-creation, orchestrated by networks of the organisations providing these services. Due to the paradigm shift and changes in the environment, the form of the provision of social services needs to be transformed, as the provision of complex and innovative services requires multi-organisational collaboration, regardless of the sector that the organisation operates [38].

It is worth noticing that the intensity of changes towards the "service" direction has resulted in the term "welfare state" increasingly replaced by "social services", better reflecting the specific organisation of the social policy system concentrated on services. The potential is also recognised in the services provided as part of a welfare society or active social policy [39-42] and the necessity of a new approach towards social policy as the policy of innovative social services-instead of the policy of redistribution of provisions (benefits) or financial resources-is emphasised. Accordingly, it is essential to invent such a form of social services delivery that would stimulate the creation of innovative solutions and at the same time have the character of social policy combining the activities of the local government and civil society entities (such as non-governmental organisations or social enterprises) with the involvement of citizens in the local community. All of that gives space for adopting a co-creation perspective on social services delivery, being all about replacing the ordinary consumer of services with the consumer who, 
at the same time, is also the producer and end-user of those services, whose role is not limited only to the consumption of services, but also includes participation (to a lesser or greater extent) in the process of their production. To simplify, this participation may occur in the phase of service development and/or during its delivery. Such co-creation of social services delivery may be addressed to various actors, e.g., (1) socially excluded, marginalised or at risk of marginalization, (2) local government and its entities that are responsible for providing social services, (3) non-governmental organisations interested in providing social services, and (4) social economy entities. Obviously, creating value through joint activities and working beyond the boundaries of a traditional, autonomous company or legal entity involves the necessity of working systemically with stakeholders, but it results in cost reduction, performance improvement, enhanced service levels, and increased stakeholder satisfaction, which are achieved by listening to citizens and customers [43] (p. 161). Besides, using a citizen-centric approach while executing complex projects is also essential to reduce the risks of failure (as risks associated with it are shared) and boost adoption [29]. Lastly, with the co-creation, the final success of social services delivery increases (measured by the degree to which citizens' needs are satisfied), citizens can participate in public life more actively, and the new type of relationship is created-direct, real, and based on cooperation between the state and citizens. As services are related "with" and developed "by" users, instead of being delivered "to" and "for" them, they often lead to new forms of management, better forms of community activity, improved integration, and better participation of end-users.

As it was already mentioned, adopting a co-creation perspective allows various actors with a shared vision to collaboratively create an environment for innovation and action. Co-creation can be seen as the form of a temporary alliance (partnership) composed for a specific project, with high levels of partner interdependency for the duration of the project. The external partners strengthen the authority's (leader organisation) competence base and innovation processes with the inflow of expertise, competence, experiences, and resources. However, adopting the co-creation perspective in the public sector raises specific challenges. First of all, public sector entities tend to be large and complex, and their leaders typically manage them from the top down. Hence, it may be difficult for them to adopt an organisational model relying heavily on the bottom-up engagement of employees, customers, and other stakeholders [34] (p. 42). Secondly, the ability to manage such collaborations efficiently is likely to be difficult because there are no mutual liabilities, especially at the early stages of the collaboration $[13,44,45]$. As various organisational actors have very little knowledge of each other, time is necessary in order to understand the corporate cultures and strategies of every organisation involved in the partnership [42]. Therefore, what is crucial for the success of this temporary alliance (partnership) is the transformation in how the authority (leader organisation) manages the development process, especially in how the authority sources complementary external partners for development and organises the service development process [46] (pp. 367-368). If this is done in the proper way, it may lead to a 'win-win' situation for all involved parties.

\subsection{Partnership as the Way for Co-creation in Social Services Delivery}

A growing awareness of the complexity of social issues contributes to the intensive search for new ways of providing social services and creating public value. Organisations providing social services reach out towards solutions crossing over their individual boundaries and create organisational projects that are based on cooperation between partners from different sectors [47,48]. In this sense, interorganisational cooperation becomes interaction fields populated by autonomous but interdependent actors, where alignments of interests institutionalized through formal collective actors and informally through issue-based nets criss-cross the established order of economic exchange relationships [49]. Less or more institutionalised cooperation between organisations is a way to earn an innovation and relational rent [50] (p. 10). The ultimate outcome of the actions that were taken should be the success measured with created value, as evaluated by individual beneficiaries, organisations forming the cooperation network, a partnership as a whole, and the local community. Relationships 
that are developed within a partnership can be perceived as voluntary links between the systems, organisations, and individuals who are involved while maintaining their autonomy. Entities operating in such a structure may remain in strong relationships with each other or such connections may be weak, yet still driven by the vision of what to strive for and how to achieve it $[51,52]$. In structural terms, partnerships are new organisational projects that can be treated as metaorganisations. Their emergence raises the necessity for seeking rules and routines that will ensure the success of a partnership when applied in their management. Participants of partner initiatives are organisations that, cooperating with each other in formulating and implementing local development programs, are more active than others and feel the need to shape local development. Their task is to represent the interests of both the entire community and institutions crucial to the community. In order for the partnership to bring the greatest results, it is necessary to develop the mechanisms for communication, decision-making, and implementation. Therefore, agreements are concluded between the partners-formal or not. The combination of resources, knowledge, and competencies of individual participants makes them dependent on one hand, which may cause certain tensions and problems, but on the other hand, such cooperation is a way to an innovative and relational rent.

One example of cooperation started between organisations operating in different sectors is public-social partnership. In principle, metaorganisations of this kind aim to develop novel ways of providing social services that are indispensable in solving problems related to i.e., the social exclusion of devalued social groups. The phenomenon of collaborations means that the involved organisations may be perceived as structures building a particular form of operation, or rather co-operation of public and social entities, or as forms that are new structures created by these entities in their endeavours to achieve a common goal [53]. The common feature of these new structures is the fact that the organisational actor (i.e., the organisation forming part of the metaorganisation that is a public-social partnership) is where control and coordination mechanisms are based. In order to better understand this type of project, the concept that was developed by Fjeldstad et al. [54] may be used. The researchers propose that research orientation adopted to diagnose management rules and routines inside the initiated collaboration (e.g., a partnership) should be changed from understanding such collaboration in terms of organisational structures to perceiving them as the rules the adoption of which allows for actors to perform their organisational roles and relations. This change in the approach offers a dynamic perspective of an organisation and its related partnership adjusting to a constantly evolving environment. They also claim that the approach that is based on organisational actors can be used universally [54]. In our opinion, the actor-based orientation is particularly suited to entities dealing with unstructured or poorly structured problems, which, due to political implications, are characterised by a high degree of uncertainty as to their actual goals and desired outcomes. This is especially relevant for public-social partnerships.

Due to significant volatility, dynamics, and unpredictability in the environment of public-social partnerships, changing organisational actors need to accommodate each other so that predictions about an unknown future can be made, optional scenarios of effective intervention in a dynamic and uncertain environment can be created, and chosen strategies can be implemented effectively and efficiently [55]. One can risk a supposition that an actor-oriented scheme is an administrative technology - the way in which the leader performs its role [56]. If this new technology follows the route of "disruptive innovation" [57,58], it may become a dominant organisational structure. This, however, does not put an end to hierarchy. In order for actors to hold authority that is needed to allocate and use resources, hierarchical contractual relations may be necessary. Therefore, it appears that where hierarchy will emerge, it will be used mainly to control, not to coordinate.

In order to achieve the sustainability of a partnership it is necessary to understand how a given partnership is managed, as how its leader manages its constituent organisations in order to achieve success and create desired public value. The literature review regarding public management models [59-82] allowed for us to come up with managerial practices undertaken as part of management in public-social partnerships, belonging to one of three management model paradigms: Public 
Administration, New Public Management, or Collaborative Public Management (see Table 1). Public Administration (interchangeably in subject literature: centralised management or hierarchical management) is based on the use of bureaucratic mechanisms where the implementation of public tasks in accordance with the law is the only course of action in the organisation. The basic principles of this model are the pursuit of rational organisation of administration, separation of staff from ownership, separation of policy from administration, hierarchy of power, and restrictive allocation of tasks to be carried out. From the point of view of management, a remote possibility of a manager to interfere in the scope of tasks and the methods of financing. New Public Management (decentralised management or market-driven management) assumes the use of market mechanisms and the supremacy of efficiency criteria. The functioning of the public sector is based on rules that are similar to the functioning of the private sector, where the citizen becomes a consumer of public services. From the point of view of management, the attention of the manager is focused on launching competition in the provision of public services between public agencies, companies, and non-governmental organisations, replacing administrative and hierarchical organisational culture with the entrepreneurial and market one, as well as control that is focused on recognizing the effectiveness and efficiency. In Collaborative Public Management (governance, network-based management), the emphasis is placed on the relations with stakeholders understood as citizens, non-governmental organisations, or entrepreneurs. The main rules of exercising authority are participation and consultation, openness, transparency, accountability, and sustainable development. From the point of view of management, the manager must undertake actions that will provide him with stakeholders support.

Table 1. Characteristics of managerial practices depending on the public management model.

\begin{tabular}{|c|c|c|c|c|}
\hline \multicolumn{5}{|c|}{ Management Model Paradigm } \\
\hline $\begin{array}{l}\text { Managerial } \\
\text { Practices }\end{array}$ & Public Administration & New Public Management & $\begin{array}{l}\text { Collaborative Public } \\
\text { Management }\end{array}$ & $\begin{array}{l}\text { Managerial } \\
\text { Practices } \\
\text { Literature } \\
\text { Source }\end{array}$ \\
\hline \multirow{4}{*}{ 1. Efficiency } & $\begin{array}{l}\text { The degree of political } \\
\text { objectives accomplishment }\end{array}$ & $\begin{array}{c}\text { The degree of economic } \\
\text { objectives accomplishment }\end{array}$ & $\begin{array}{l}\text { The degree of social objectives } \\
\text { accomplishment }\end{array}$ & \multirow{4}{*}[60,61]{} \\
\hline & Allocation structure & Economic results & Outcomes & \\
\hline & $\begin{array}{c}\text { Inability to achieve } \\
\text { individual organization } \\
\text { objectives }\end{array}$ & $\begin{array}{l}\text { Limited by contract terms, } \\
\text { opportunities to achieve } \\
\text { organizational objectives }\end{array}$ & $\begin{array}{l}\text { Ample opportunities to } \\
\text { achieve organizational } \\
\text { objectives stimulated by } \\
\text { partnership agreement }\end{array}$ & \\
\hline & Rigid, not negotiable goals & $\begin{array}{l}\text { Objectives modification, as a } \\
\text { direct consequence of } \\
\text { fluctuations in the economic } \\
\text { environment }\end{array}$ & $\begin{array}{c}\text { Objectives modification, as a } \\
\text { direct consequence of } \\
\text { fluctuations in the social } \\
\text { environment }\end{array}$ & \\
\hline \multirow{5}{*}{$\begin{array}{l}\text { 2. Public } \\
\text { liability }\end{array}$} & Political & Individual of an entrepreneur & Divided across partnership & \multirow{5}{*}[62,63]{} \\
\hline & $\begin{array}{l}\text { Small possibility to negotiate } \\
\text { with local authorities about } \\
\text { problems affecting the } \\
\text { society }\end{array}$ & $\begin{array}{l}\text { Possibility to negotiate with } \\
\text { local authorities about } \\
\text { problems affecting the society }\end{array}$ & $\begin{array}{l}\text { Organizational capability to } \\
\text { direct resources and attention } \\
\text { to upcoming social problems }\end{array}$ & \\
\hline & $\begin{array}{l}\text { Poor information flow } \\
\text { outside the system of power } \\
\text { about the objectives and } \\
\text { results of operations }\end{array}$ & $\begin{array}{l}\text { Objectives and results of main } \\
\text { organizational activities } \\
\text { available within the system of } \\
\text { power and contracting parties }\end{array}$ & $\begin{array}{l}\text { Objectives and results of main } \\
\text { organizational activities } \\
\text { available within partnership } \\
\text { and stakeholders }\end{array}$ & \\
\hline & $\begin{array}{c}\text { Obtained results monitored } \\
\text { only for the purpose of } \\
\text { authorities }\end{array}$ & $\begin{array}{l}\text { Obtained results monitored as } \\
\text { a part of system of power and } \\
\text { for the contractors needs }\end{array}$ & $\begin{array}{l}\text { Obtained results monitored as } \\
\text { a part of system of power and } \\
\text { for the dialogue with } \\
\text { stakeholders }\end{array}$ & \\
\hline & $\begin{array}{l}\text { Penalties under the system } \\
\text { of power }\end{array}$ & $\begin{array}{l}\text { Penalties according to contract } \\
\text { agreement }\end{array}$ & $\begin{array}{l}\text { Penalties within partnership } \\
\text { and external environment }\end{array}$ & \\
\hline
\end{tabular}


Table 1. Cont.

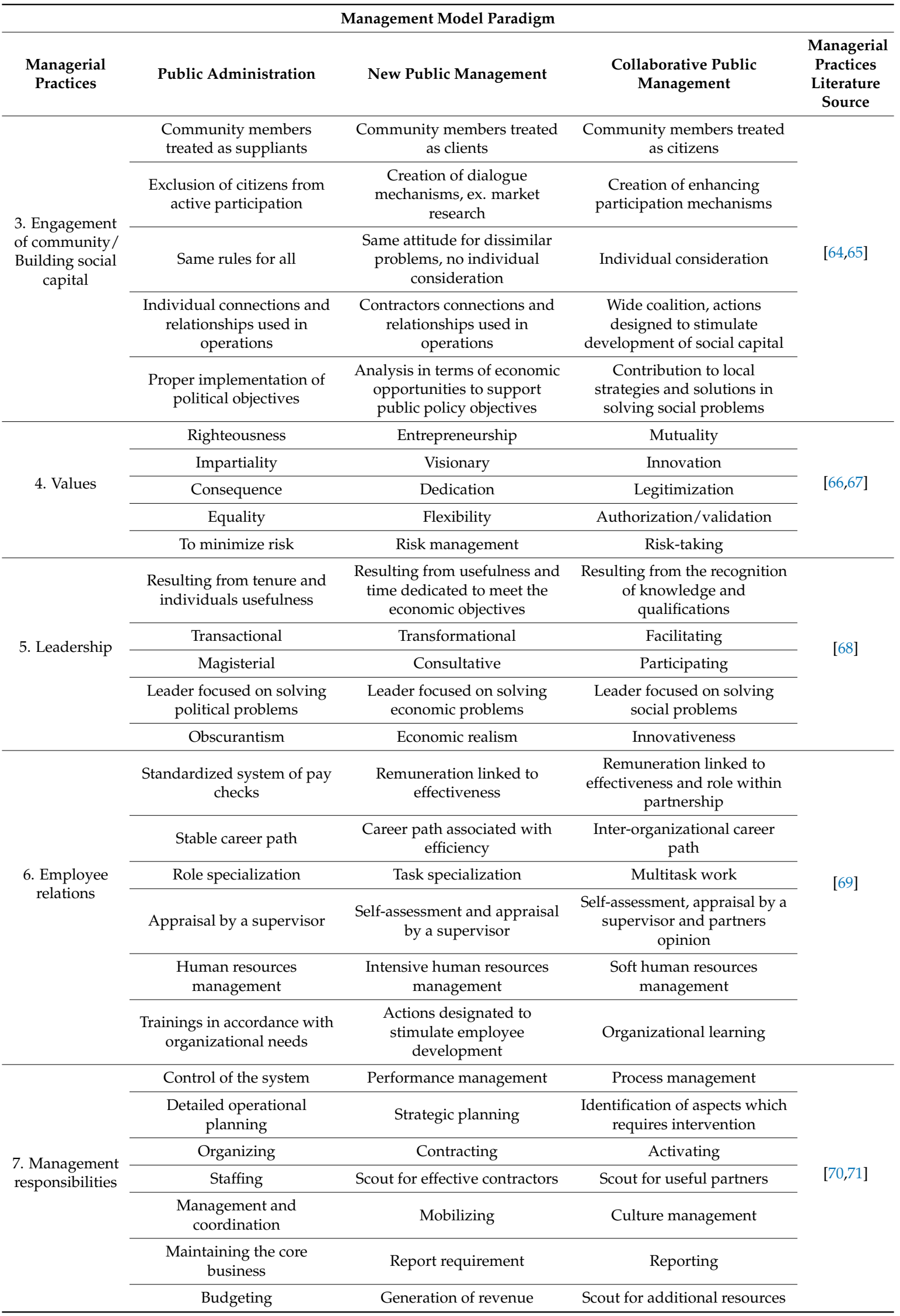


Table 1. Cont.

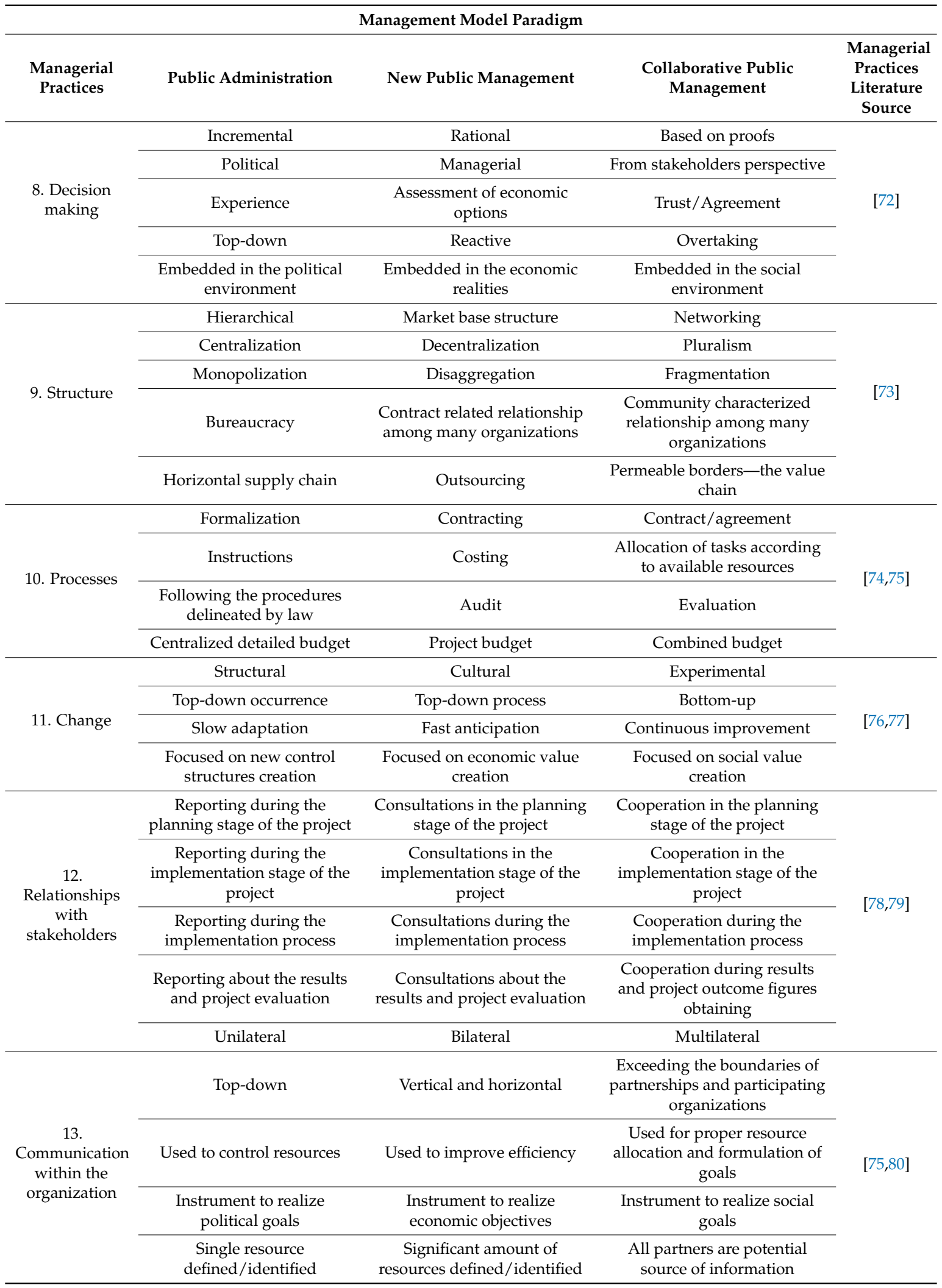


Table 1. Cont.

\begin{tabular}{|c|c|c|c|c|}
\hline \multicolumn{5}{|c|}{ Management Model Paradigm } \\
\hline $\begin{array}{l}\text { Managerial } \\
\text { Practices }\end{array}$ & Public Administration & New Public Management & $\begin{array}{l}\text { Collaborative Public } \\
\text { Management }\end{array}$ & $\begin{array}{l}\text { Managerial } \\
\text { Practices } \\
\text { Literature } \\
\text { Source }\end{array}$ \\
\hline \multirow{4}{*}{$\begin{array}{l}14 . \\
\text { Organizational } \\
\text { culture }\end{array}$} & $\begin{array}{l}\text { Relations based on mutual } \\
\text { allocation of tasks }\end{array}$ & $\begin{array}{l}\text { Relations based on willingness } \\
\text { to make an effort }\end{array}$ & $\begin{array}{l}\text { Relations based on shared } \\
\text { values }\end{array}$ & \multirow{4}{*}[81]{} \\
\hline & Meritocracy & Entrepreneurship & Creativity & \\
\hline & Acceptance of role & Openness to achievements & Openness to visionary & \\
\hline & $\begin{array}{l}\text { Good implementation of } \\
\text { assigned tasks }\end{array}$ & Good process organization & Elastic adaptation & \\
\hline
\end{tabular}

Source: own elaboration on the basis of subject literature. [59,82]

Taking into consideration the very nature of a partnership, being multi-stakeholder collaboration, we clam that that using managerial practices typical of Collaborative Public Management foster sustainability in partnerships and should therefore be preferred in partnerships focused on social service delivery.

The main value of the managerial practices that are presented in Table 1 is that it facilitated coding, analysing, and comparing managerial practices within public management models, serving as a framework for transparent distinctions in managerial behaviour. The proposed typology also contributes-through reflective revision-to controlling the subjective assessments of the researcher, while facilitating the theory building [83] (p. 194). Obviously, our proposition is not perfect, as some compromises were required in order to make sure that it is neither too reductionist in minimizing complexity, nor too deterministic in adjusting data to predetermined categories. However, since no typology is able to adequately describe all phenomena, management practices do not always exactly match the predetermined categories, and as such final selection and evaluation depend on the researcher.

\section{Materials and Methods}

\subsection{Research Design}

The literature review regarding public management models allowed for the formulation of the research goal as exploration, categorization, and interpretation of how the leaders of organizations included in the public-social partnership managed established partnership and how manager of the partnership managed it. Consequently, we posed the following research questions:

1. How do managers engaged in a public-social partnership operate?

2. Which model of public management-Public Administration, New Public Management, or Collaborative Public Management-is conducive to achieving better results in the public-social partnership?

In response to the questions raised, first we integrate insights from different strands of literature. Next, empirical data are derived from two main sources, one specific case-the public-social partnership established by 18 institutions and organisations, followed by quantitative research that was conducted in 173 partnerships in Poland.

The partnership we have focused our research attention on was established to design and revive institutional support for people marginalized or at risk of marginalization in the City of Rybnik, Śląsk, Poland. Researched partnership consisted of 18 entities-six public organisations and 12 social organisations. The longitudinal study involved the close and intensive analysis of the context and dynamics of collaboration within the partnership, which resulted in the identification of management practices and contributed to the determination of the implemented management models and the formulation of conclusions. 
The first stage of our research, being data gathering process, started at the end of 2011 and it has taken the form of participant observation in the process of partnership formulation as well as document analysis. As pointed out by R.E. Stake [84], the choice of a particular case to study is often determined by the individual interests and preferences of the researcher rather than by methodological reasons. As the researcher chooses the organisational reality that is fascinating for him and that he tries to explore, hence the selection of research techniques is secondary and dictated by pragmatism. Indeed, the authors' hands-on experience in facilitating the launch of partnerships has equipped them with an opportunity to carry out a longitudinal study, allowing for successful data collection, on one hand, and facilitating communication within the partnership on the other hand. This approach is in line with Van de Ven's [85] engaged scholarship, which emphasizes the co-production and co-ownership of the research process and challenges visions of academics as the sole knowledge producers and drivers of academic inquiry [86]. In the period of time 2012-2014, the researchers have also made c.a. $200 \mathrm{~h}$ of observation and participated in networking meetings for organisations forming the partnership. In addition to the data collected in the course of the study, the researchers also used their own experiences and personal notes from the period of time when they had been working with the partnership as facilitators and evaluators. This is in line with Eisenhardt [87] and Yin [88], who value the possibility of the joint use of different data collection techniques. In order to support evidence from field research, secondary data were used as well (the partnership website, newspaper articles, and annual reports).

These steps were next supplemented with the information that was elicited from in-depth interviews (IDIs). The targeted participants were 18 leaders of the organisations constituting the partnership. Within the period of two years (2015-2016) the researchers have conducted 18 interviews-one in each organisation. Each interview lasted between 50 and 150 minutes and was recorded for content analysis purposes. We have asked participants to describe management practices used in their organization, and used by the manager of the partnership.

Subsequently, we showed respondents the description of 14 managerial practices in relation to the public management model provided by literature (Collaborative Public Management, New Public Management, and Public Administration-see Table 1) and asked to indicate the statements that characterize his or her style as well as manager of the partnership style. The key to the systematic qualitative analysis [89] was the compilation of the characteristics for 14 management practices. It was assumed that when a respondent chose the characteristics of a particular management practice and discussed the reasons for his choice, it would be possible to make conclusions about the occurrence of behaviours representative of one of the three ideal models of public management. The value of the developed typology rested in the fact that it facilitated the coding, analysing, and comparing of management practices within the models, as it acted as a tool providing the framework for clear distinctions relating to managerial behaviours and seeking relationships between a management method and achieved results. The features described for each public management model have been numbered, e.g. for managerial practices in terms of efficiency, the numbering is as follows: the degree of political objectives accomplishment (Variable 1), allocation structure (Variable 4), inability to achieve individual organization objectives (Variable 7), rigid, not negotiable goals (Variable 10), the degree of economic objectives accomplishment (Variable 2), economic results (Variable 5), limited by contract terms, opportunities to achieve organizational objectives (Variable 8), objectives modification, as a direct consequence of fluctuations in the economic environment (Variable 11), the degree of social objectives accomplishment (Variable 3), outcomes (Variable 6), ample opportunities to achieve organizational objectives stimulated by partnership agreement (Variable 9), and objectives modification, as a direct consequence of fluctuations in the social environment (Variable 12). The data was analysed jointly by both authors using a timely and rigorous process, starting with a detailed analysis of each IDI. Each interview was first transcribed and carefully analysed, the following stage of data analysis was interpretation and the final stage was the analytical discussion, engaging existing literature to provide theoretical explanation for the identified managerial practices. 
In order to acquire a complete picture of managerial practices in the examined partnership, cluster analysis based on the hierarchical method $[90,91]$ was used to identify the relations between variables. The distances were determined using Ward's method, which defines the dissimilarities between objects as mean squared distances between cluster centres:

$$
d_{A B}=\frac{n_{A} n_{B}}{n_{A}+n_{B}} d^{2}\left(\bar{x}_{A}, \bar{x}_{b}\right)
$$

The optimal number of clusters makes the highest quotient of between-group variance to within-group variance. The criterion is known as the Caliński and Harabasz [92] index.

Following the proposed methodology, we looked for similarities in terms of the subjective assessment of the management practices applied within the partnership. Cluster analysis, which aims to identify objects in a set that are similar to each other and group them into clusters, was used to interpret the elicited responses. At the start, we assume that each element forms a separate group, and then we gradually weaken the criterion of recognizing objects as the same, which allows for grouped similar objects. As the criterion is further weakened, more and more objects are group together and they aggregate to form larger clusters that are increasingly different from each other. Finally, in the last stage, all objects are grouped together. As a result, the method yields a dendrogram that is a binary tree diagram, where nodes represent clusters, while leaves-classified objects. The analysis of all objects (14 management practices) allowed for the grouping and creating of a set of classes containing similar opinions in terms of aggregated subjective judgments. Based on its results, a measurement tool was designed for the quantitative study (diagnostic survey).

In the second stage, the questionnaire-based survey was carried out. The market research company contacted by telephone leaders of public-social partnerships from randomly selected 300 partnerships operating throughout Poland. The data were gathered by between September and December 2015. Respondents declared if they are willing to participate in the research and answered to a screening question: are you a leader of public-social partnerships? If respondent agreed to participate in the research and answer to the first question was positive, the questionnaire was sent prior to telephone contact by an interviewer (CATI). Next, the dataset was reviewed for incomplete responses, outliers, and uniform responses across all scale items. From the original, contacted by the telephone research sample, we gathered 201 completed questionnaires, of which 173 were included in the research. These procedures yielded an effective response rate of $57.6 \%$. The survey used a 58-question questionnaire. Most questions adopted a seven-level Likert scale and the respondents were asked to evaluate each characteristic on a scale representing different degrees of approval for a given statement (1-lack of approval for a proposed version of a response, 7-total approval for a proposed version of a response). The remaining questions offered cafeteria-style checklists, which were exhaustive in terms of the responses that could be given to a particular question. It is important to note that this paper presents only one of many studied aspects, namely the connection, declared by the leaders, between the public management model applied in a particular partnership and the success in creating public value (questions 51,57).

\subsection{Empirical Findings}

\subsubsection{First Stage-Research Results}

The following section contains a description and analysis of the management practices categorized based on the public management models provided by literature (see Table 1), being a result of 18 conducted IDIs. In this section, management practices that are used in the researched partnership are broken down into 14 components (from 1-efficiency to 14-organisational culture). Each of the managerial practices was illustrated with specific dendrogram. The obtained responses regarding each managerial practice have been individually interpreted and summarized. 
In the examined partnership, the management practices that affect the organisation's efficiency combine the instruments typical of Public Administration, New Public Management, and Collaborative Public Management models with a slight advantage of the last one. The partnership is an organisation of high complexity in terms of its organisational form, so one of its features affecting efficiency is a variety of interdependencies between its constituent organisations. The respondents emphasized the particular attention that the manager attached to the stimulation of community mechanisms, the conciliatory redefinition of goals as a result of changes occurring in the task-related environment, the effective information policy, the involvement in the dialogue with stakeholders, and, finally, the management of relationships within the established collaboration scheme.

The combination of Public Administration, New Public Management, and Collaborative Public Management models-with the strongest presence of management practices typical of the New Public Management model - was indicated as the way to implement management practices related to the aspects connected with public liability. In the case study, the manager of the partnership builds the cooperating organisations' awareness of the role that they have undertaken and of the fact that the quality of the pursued initiatives contributes both to their individual image and the overall image of local political authorities. The respondents stress that the manager's awareness that the effective implementation of the partnership's goals is to create desired outcomes for the local community and the participation of partner organisations legitimises their operations and contributes to increased social approval and a prolonged political mandate.

The cluster that emerged for management practices related to engagement of community/building social capital clearly favoured management practices typical of the Collaborative Public Management model. This implies that the manager of the partnership is perceived as a one who appreciates the significance of local community involvement for the success of the partnership's initiatives. The manager understands and collaborates organisations that recognise that the partnership, as a structure operating in a given local environment, has to cooperate with it, building relationships both with individuals and organisations. Relationships are developed in more or less organized structures, constantly evolving in a particular environmental context. The success of the partnership based on common good creation, responsibility, and transparency contributes to building the stronger norms of trust, boosting the social capital necessary to pursue the adopted goals.

The distribution of the responses relating to the management practices in the area of values indicates that the management practices that are adopted combine the instruments characteristic of Public Administration, New Public Management and Collaborative Public Management models. The management practices that were upheld strongly by the manager are the norms of mutuality, legitimization, validation, and innovation. Although one of the most difficult challenges facing the partnership's manager is to build a coalition that is based on shared values, the respondents underline that it has been successfully achieved in this partnership. The member organisations constituting a newly created structure contributed their own ethics, which occasionally meant the lack of neutrality in terms of the values created in the network. In the process of creating the partnership's mission, the manager confronted the expectations of the member organisations with the partnership's goals and initiatives, aiming to achieve compromise.

The survey results show that the respondents from the partnership claim that, in the area of leadership, the manager combines the instruments typical of Public Administration, New Public Management and Collaborative Public Management models. Managing the partnership is perceived as a complex process, because the manager has to be able to skilfully merge the different logics of partner organisations. The joint management structure acts as an integrating system, which results in the institutionalised leadership that allows for the nominal manager and leaders of the member organisations to connect substantially different parts of the partnership. The permeable boundaries of the partnership further increase its complexity, and, as a result, cause the emergence of conflicts, which are resolved by the nominal leader, striving to strengthen the platform that is shared by the organisations. 
In the area of management practices concerning employee relations, cluster analysis points to dominance, however, weak, of practices related to the New Public Management model. The respondents emphasise that the solutions that are adopted in the field of employee relations have to comply with the current legislation, which tends to regulate HRM procedures in a relatively inflexible manner. The manager understands that human resources management is the key to effectiveness irrespective of the management model and he seeks to boost this aspect in the partnership. Employee relations, and-more broadly-human resources management, are the key to creating added value in the public-social partnership, because, as stressed by the respondents, these organisational structures by nature do not have a more important resource than their employees.

Based on the responses to the questionnaire, the clusters generated for management practices in the area of management responsibilities point to the combination of the instruments typical of the Public Administration, New Public Management and Collaborative Public Management models. The respondents indicated that the manager of the partnership effectively activated and motivated the representatives of all partner organisations to build and develop the network and boosted efficiency through seeking and raising resources ensuring the improved quality of services delivered. The leaders in the constituent organisations make a concerted effort working to achieve mutual benefits stemming from their initiatives. The manager recognises that the contribution and individual competences of each partner are compatible and he uses his knowledge to raise such resources from partner organisations that are needed at a particular moment.

The analysis of the clusters that emerged for the management practices in decision-making reveals the combination of the instruments typical of the Public Administration, New Public Management, and Collaborative Public Management models. The respondents claim that the manager attaches importance to the decision making process, so that the decisions taken can be based on the shared evaluation of the needs and threats relating to each service user, which stimulates the development of alternative solutions, which would otherwise remain unconsidered. The manager's pursuit of synergy involves maximizing the mechanism of the identical assessment of all partners as an important aspect of conducted activities. Cumulative and sequential operations build a coherent programme of creating socially desired value. Conflicts seldom emerge and if they do, their resolution does not entail inadequate use of power.

The clusters acquired for the structure-related management practices confirm the emerging pattern that the manager of the partnership can combine and counterbalance the management practices of all the three models, choosing the solution that is the most suitable for a particular situation. This opinion was formulated by the respondents based on the observations of changes in the make-up of interorganisational collaboration, the way of choosing new members or eliminating those who did not allocate sufficient resources for the common good. The partnership in question is a heterogeneous structure, with a number of partners and imperfect communication between the strategic party (leader) and the operational parties (organisations constituting the network) that have varied motivation to initiate actual action. The group that holds real managing authority consists almost exclusively of the employees of the public organisation and operates as a system with permeable boundaries and closed membership. The proposed structure of the partnership reflects the need to overcome weaknesses that are inherent both in the hierarchy and are typical of market reliance on individual organisations and specialization. It also reveals the tension between the social need of a still higher-level specialist professional expertise and the individual need expressed by the consumer or the customer to receive a holistic, accessible service.

The distribution of clusters grouping the opinions on the process-related management practices shows that the respondents do not opt for a strong dominant management model. Yet, clusters for the Collaborative Public Management and Public Administration models are slightly stronger. The preference for the collaborative management dimension is manifested in highlighting the fact that the leaders of the partner organisations invest time and energy to ensure learning in the co-participation contexts, which allow for hidden knowledge and experience to be transformed and diffused, bringing 
benefits for the entire partnership. Power is used interactively and dynamically through social network relations that are embedded in mutual co-dependencies. Protocols are process standards, designed to build up trust by creating obligations between partners. Such formalization, however, does not always result in the emergence of more significant relations on a strategic level, where trust from peripheral organisations is lower. The respondents opine that official supervision or passive submissions are not sufficient to achieve positive outcomes in the collaboration.

The distribution of clusters for the management practices relating to organisational change shows a slight dominance of the Collaborative Public Management model adopted in the partnership. The manager of the partnership plays the key role in implementing institutional changes, initiating them based on the information about such a need acquired from the collaborating organisations. The respondents see the actions taken by the manager in this respect as the approval for bottom-up initiatives, proposing adjustments to the complex goals that are pursued by the partnership. This means that all partners are fully recognised as legitimate participants in the process and their opinion on the need to make adjustments and reviews is taken into account. It is essential that all partnership members support the mechanisms that are used to initiate steps aiming at continuous improvement and seek such goals that carry significant value for a local community. The manager approves of the need to respond to changing internal and external objectives. He prefers, however, incremental changes, introduced on a small scale, due to the fear of the reduction in the partnership's social capital.

The examination of the clusters reveals that the respondents perceive the management practices in the area of stakeholder relationships as the combination of the Public Administration and Collaborative Public Management models. The respondents emphasise that managing the partnership cannot be separated from stakeholder relationships, since the key to success is to identify and reinforce the strategic ability to create maximum value for major interested parties at reasonable costs. In the times when resources that are allocated to satisfy public needs are being limited, social expectations are growing, people are becoming increasingly sceptical about public institutions, and pressure on delivering quality is becoming stronger, the provision of services at a level that would be satisfactory for stakeholders is becoming a difficult task. Hence, it is particularly important to maintain relationships with stakeholders during the entire strategic management process, because "success" of the partnership—and its survival-depends on satisfying key stakeholders according to their definition of value.

The analysis of the clusters indicates that the dominant management practices in the area of communication within the organisation are the practices using the instruments typical of the Collaborative Public Management model. The respondents stress the active role of the manager in building synergic communication patterns. The typical behaviour of the manager is crossing over the boundaries of the organisation in order to use the resources available from organisational actors in an appropriate way. The organisations joining the partnership are aware that not all of the partners are equally engaged in the initiatives launched and express criticism towards this lack of involvement. The manager, however, attempts to facilitate the information flow between organisations. An important aspect of the communication process, as emphasised by the respondents, is the influence of the knowledge acquired by the manager about the state and structure of the resources in the partner organisations and the fact that all partners are treated as potential source of information.

The analysis of the clusters characterising the management practices relating to the development of organisational culture reveals that the manager uses the combination of the instruments from all the three models. A slight preference-in terms of the uniformity rather than strength of the cluster-is detected in the case of the Collaborative Public Management model. The manager of the partnership skilfully controls the organisational actors by defining the mission clearly and focusing energy and resources, coming from partner organisations, around this mission. Additionally, has developed specialist operational strategies and crisis intervention methods. The partnership has a dominant task-driven culture with a certain tendency to cross the organisational boundaries. This culture promotes behaviours that are oriented towards collaboration opportunities. The manager is not interested in ensuring the positions of individual organisations, but concentrates on the legitimization 
stemming from joint undertakings. The respondents underline that good relationships with the partners and orientation towards collaborative effort decrease entrepreneurship and innovativeness, which raises concerns that the benefits generated are lower than expected by the partner organisations. The positive aspect, on the other hand, is the atmosphere of cooperation and a sense of self-esteem that the managers of the collaborating organisations can develop.

Findings regarding the most frequently used managerial practices by both the manager and leaders of organisations constituting the researched partnership are presented in the discussion part.

\subsubsection{Second Stage-Research Results}

The distribution of the responses to the question about the dominant public management models in the 173 partnerships surveyed was almost equal as the results obtained in the first stage of our research. $38.2 \%$ of the leaders pointed to the New Public Management model as the dominant one, while the practices typical for the Collaborative Public Management and Public Administration models received similar ratings- $-30.6 \%$ and $31.2 \%$, respectively (see Table 2). The evaluation of the outcomes and a sense of achievement are particularly important for the existence and growth of the partnership and its sustainability. The positive evaluation will ensure continued participation in the established collaboration network and encourage new entities to join the network. The distribution of the responses reveals that nearly half of the respondents assess the achieved outcomes as average. It is not a result that speaks well of the effectiveness of the actions initiated. On the other hand, 1/3 of the managers of the partnerships perceive the outcomes as good or very good, while only $1 / 5$ of the respondents-as poor or very poor.

Table 2. Public management models and subjective perceptions of success as evaluation of collaboration outcomes-cross table $(\mathrm{N}=173)$.

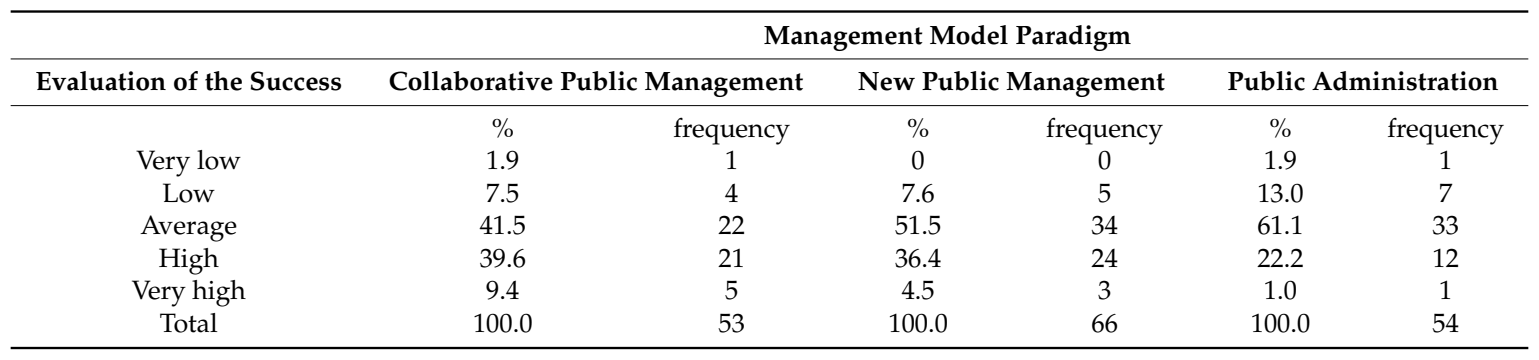

The comparison of the management model indicated by the leader with the perceived success of collaboration reveals that the perception tends to be better or much better in the partnerships with the dominant model of Collaborative Public Management. Similar results were achieved for the partnerships that adopted the New Public Management model, whereas the Public Administration model tended to correspond with poor or very poor perceptions of the partnership's outcomes (see Figure 1).

The fact that the respondents claimed that the most effective partnerships were the partnerships whose managers mostly used the techniques characteristic of the Collaborative Public Management model highlights the importance of co-production for public value creation as a way of achieving sustainability of a partnership. We should bear in mind, however, that the success of the partnership means the achievement of positive outcomes that could not be achieved if partner organisations operated separately, and the outcomes concern the partner organisations, the partnership as a metaorganisation, and the entire local community [93]. It means that in order to achieve goals and create value, the manager of the partnership, apart from adjusting management practices to a situation, has to be able to integrate the intraorganisational perspective with the context in which a newly created structure operates. 


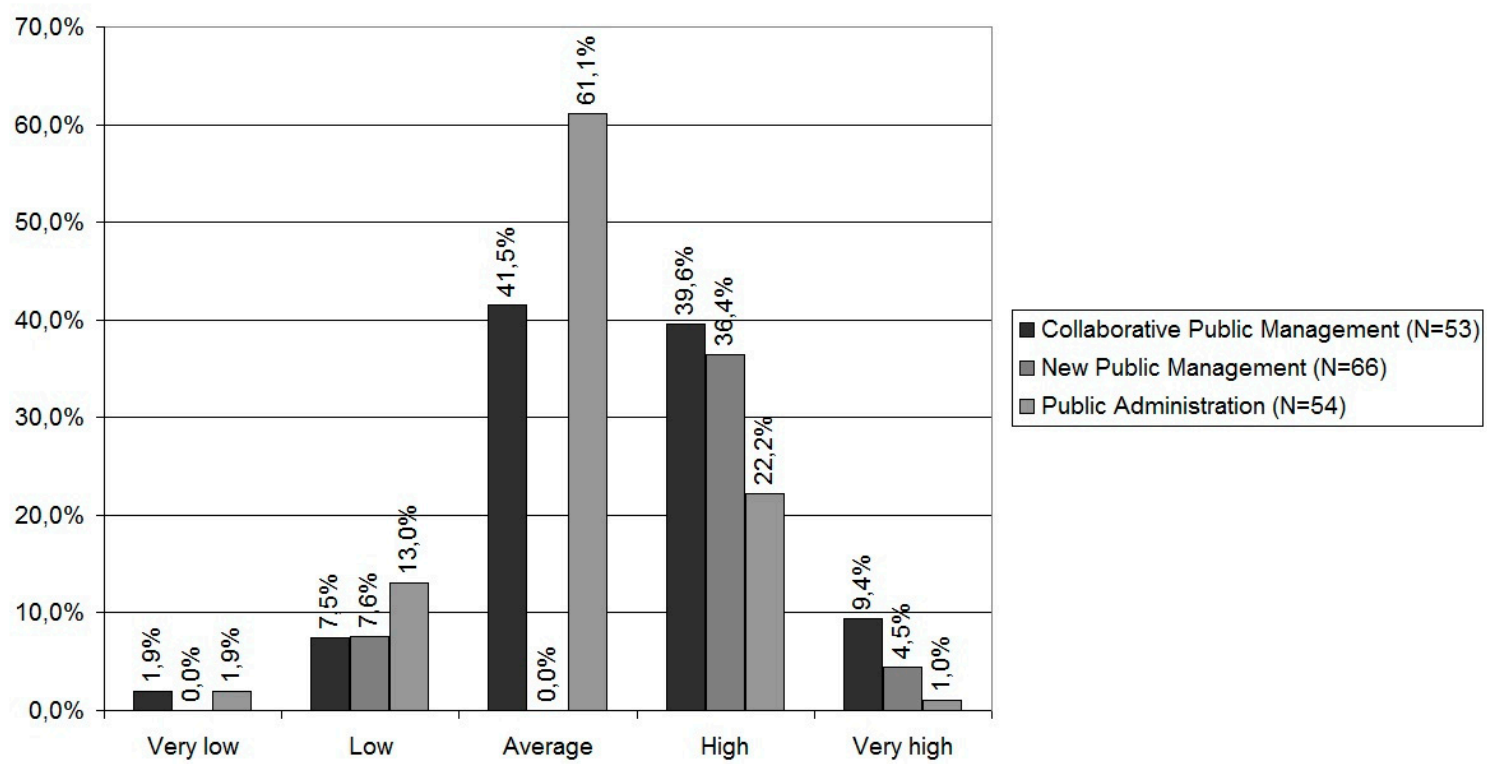

Figure 1. Public management models and subjective perceptions of success as an evaluation of collaboration outcomes $(\mathrm{N}=173)$.

\section{Discussion}

Based on the presented case study, analysis of the survey results and IDIs conducted with the 18 leaders of the organisations constituting the partnership established in Rybnik, the observed pattern revealed the dominance of Collaborative Public Management model contributing to the success of the partnership. It was also identified what actions were taken by the manager of the partnership in order to maintain links between the partners, build trust, and win their support and legitimisation in public space-all of which is necessary to create public value, which in turn contributes to sustainability of the partnership. Although it might seem that in order to generate maximum value, a public-social partnership needs to be managed using management practices that are typical of the Collaborative Public Management, as it allows for better integration of the resources and goals of each partner organisation, it is not always the case. The research results lead to the conclusion that the three models treated as the paradigms of public management-Collaborative Public Management, New Public Management, and Public Administration-are present in the management practices of the partnership leader in different proportions (see Table 3). It should be noted, however, that the Collaborative Public Management model manifests a slight dominance, which reveals the orientation towards preference for bottom-up mechanisms and participation.

The images of the clusters (dendrograms) for particular managerial practices support the conclusion that the significance of Public Administration management model as a dominant discourse is decreasing. The focus is being shifted towards the instruments that approach collaborating organisations from a holistic perspective, seeking mechanism that would allow for each partner organisation to pursue its own growth within the partnership. As proven by our research results, leaders-according to the situation and possibilities - use managerial practices specific to different management models, and so does the manager of the entire partnership. Therefore, the consistent and homogenous management model is not the factor that unequivocally leads to the success of partnership and its sustainability. This in turn leads to the need to reflect on what actually is the factor deciding whether the partnership achieves its objectives. The observed practice shows that what leads to success is the fact that leaders use managerial practices that are better suited for running a partnership and this way they achieve better outcomes. The management of a partnership using a wide range of managerial practices is what is expected in the holistic approach to leadership, namely the application of general management skills to specific problems. The research results indicate that the difference rests in the details and subtleties concerning conscious choices made by leaders and 
manager to adjust their practices to take into account the partners' perspective and solve problems through mediation and negotiation. Time, resources, and skills are invested in interpersonal relations, because leaders know how to build and maintain a successful partnership, which will be perceived as trustworthy by partners, i.e., organisational actors and communities. Although the Collaborative Public Management model dominates—slightly, but still—in the researched partnership, the features of the remaining two models are also present in weaker forms. Answering the question why this is the case, we could risk a conclusion that none of the models corresponds fully with the complexity of management practice, so different instruments located in different management models should be incorporated and used. The study also leads to the thesis that leaders of organisations constituting the partnership perform their tasks through the adoption, adjustment, and rejection of particular aspects of management theory and practice, the development of new management methods that are better suited for the excepted outcomes in the area of improving the quality of life in a local community, which makes them aligned with the concepts of the architecture of collaboration [54]. Building and maintaining involvement require managerial skills of leadership and influencing, readiness to rely on others, and qualifications and energy to indirectly hold practitioners accountable, which is a difficult and thankless task. Supervision over management practices facilitates increased efficiency as a result of the synergism of managers' and practitioners' interest and the balance between practitioners' autonomy and liability.

Table 3. The identification of public management models in the selected management practices.

\begin{tabular}{lll}
\hline \multicolumn{1}{c}{ Dimension } & Primary Cluster & Secondary Cluster \\
\hline 1. Efficiency & Combination of models & Collaborative Public Management \\
\hline $\begin{array}{l}\text { 2. Public liability } \\
\text { community/building social capital }\end{array}$ & Combination of models & New Public Management \\
\hline 4. Values & Combination of models & Combination of models \\
\hline 5. Leadership & Combination of models & Collaborative Public Management \\
\hline 6. Employee relations & New Public Management & New Public Management \\
\hline 7. Management responsibilities & Combination of models & Collaborative Public Management \\
\hline 8. Decision making & Combination of models & New Public Management \\
\hline 9. Structure & Combination of models & Combination of models \\
\hline 10. Processes & $\begin{array}{l}\text { Public Administration/Collaborative } \\
\text { Public Management }\end{array}$ & $\begin{array}{l}\text { Collaborative Public } \\
\text { Management/Public Administration }\end{array}$ \\
\hline 11. Change & Collaborative Public Management & Combination of models \\
\hline 12. Relationships with stakeholders & $\begin{array}{l}\text { Public Administration/Collaborative } \\
\text { Public Management }\end{array}$ & $\begin{array}{l}\text { Public Administration/Collaborative } \\
\text { Public Management }\end{array}$ \\
\hline $\begin{array}{l}\text { 13. Communication within the } \\
\text { organisation }\end{array}$ & Combination of models & Collaborative Public Management \\
\hline 14. Organisational culture & Combination of models & Collaborative Public Management \\
\hline
\end{tabular}

The overall conclusion from the study is that a partnership is a process that is embedded in a context that dynamises and conditions the relationship between partners. If the relationship is to yield expected outcomes, leaders of organisations constituting partnership and the manager of the partnership have to be able to build the architecture of collaboration, as this architecture connects the constituent entities, i.e. organisational actors, into a public-social partnership. Its development and striving for its sustainability requires skill and leadership. The quality of leadership is the factor that is probably of greatest significance for the created structure of success $[88,89]$. 


\section{Conclusions}

Collaboration between partner organisations develops in response to revealed social problems and its organisational form is an architectural reaction to their existence. The necessity to build a structure in response to the identified needs causes that organisational effort is made to design such a functional structure-in other words, the architecture of collaboration-that the initiatives that are in demand in a given local community can be effectively consumed as a result of applying such methods for reaching goals that allow for collaborating organisations to achieve success. Paradoxically, it is the limitations that shape the way of organising and the solutions applied in operation. This is a slightly simplified model of defining collaboration as an organisational response to challenges arising from the social reality, but although it is not as rare as it might seem, it often ensures success and the achievement of goals. A variety of organisations that have to form a partnership, diverse resources, and, above all, the human factor make such a partnership unique. When considering the diversity of goals that partnerships are created to pursue, this becomes a significant value, but in terms of scientific analysis, partnerships elude simple classifications, hence a significant difficulty in identifying patterns and principles that regulate them. However, it is necessary to bear in mind that building a metaorganisation requires a new innovation culture, strategic vision, courage, direction, and sense of urgency. As Lee et al. [14] notices, the road to co-innovation is neither smooth nor easy and organisations do not have much choice but to join the race to become an effective value-creating organisation for competitive advantage.

The study proved that a partnership is something more than a fixed set of relationships-it has a visible logical structure, which can be referred to as the architecture of collaboration. The fact that a partnership does not normally have one dominant management model means that, as an organisational structure it is characterized, on one hand, with a degree of institutionalisation, and, on the other hand, a constant pursuit of the formula that will allow partners to design a partnership in such a way that will let them create desired public value and achieve sustainability. Such metaorganisation consisting of collaborative organizations, which are "simultaneously innovative and efficient, agile and scalable" [94] focuses on knowledge production through both internal and external collaboration. Shared values and goals are more important for the success of a partnership than strict formal rules or resources characteristic of the institutionalization of connections between the organisations constituting a partnership. The manager of a partnership and the leaders of its member organisations should be able to freely cross organisational boundaries and apply their transdisciplinary knowledge to create the vision of what may be achieved as a result of collaboration and ensure the survival of this innovative organisational structure. The complex nature of the collaboration processes needs to be analysed from a variety of research perspectives.

The research results come with a number of limitations that stem mainly from the known shortcomings of qualitative and quantitative research conducted with a survey method. First, the assessments of all the variables examined are based on the respondents' subjective opinions. This might cause a bias due to the respondents' tendency to reply positively to questions that are related to success. The inclusion of objective measures could reinforce the conclusions of this study. Limitations are also connected with the fact that we have interviewed only one respondent in each organisation. In order to decrease the risk of bias during the design and administration of our research, we assured respondent confidentiality. This is aimed at reducing common method bias by making respondents less likely to modify their answers due to social desirability or how they think that others may expect them to answer. The authors are also aware that the nature of this paper in explanatory and the research approach that is adopted in this paper does not give the right to generalization. However, it is believed that the triangulation of the data sources and longitudinal data collection process increased the level of the rigor of drawing conclusions. In general, the study should be seen as a justification for the need for future, more in-depth studies on the conditions for the functioning of public-social partnerships, and the factors determining the effectiveness of providing social services. 
Accordingly, in future studies, the success of the partnership could be analysed through the prism of the impact that the partnership has on the community, its value for particular organisations that joined the partnership, the actual costs that were incurred, and the benefits that were generated as a result of the collaboration. Another interesting research avenue could be connected with capturing the multi-level nature of both cooperation and competition in partnerships, as well as looking at it through the prism of trust and distrust. Future research could also be conducted into the structure and conditions of organisational projects in order to identify emerging connections and to provide their accurate interpretation so that theoretical knowledge about the complex organisational life can be effectively used by managers working for public organisations to improve the outcomes of their initiatives. It is also necessary to focus research attention at dark sides of cooperation as those surely exist. Although we have moved from old Public Administration to New Public Management and networked environment typical of the Collaborative Public Management model, it has to be noted that the values, practices, and approaches of each paradigm still exists and influence the decision making model.

Establishing collaboration is an element of the process-according to Wood and Gray [95], a kind of "black box" - that aims to design such a structure that will ensure the achievement of goals. The process involves collaboration occurring as continuing formal interactions and recurrent informal sequences in negotiations, obligations, and their fulfilment. Accommodation is the result of the continuing process of "trial and error", completed when the participants in an organisational project achieve significant net benefits [96] (p. 8). Game theory supports the assumption that the whole process is oriented towards collaboration that is defined as the process aiming to design and implement the architecture of collaboration that is adequate for an organisation's goals. Collaboration in a partnership is a process in which autonomous actors influence each other through formal and informal negotiations, jointly developing rules and structures of governing (regulating), and their relationships, methods of operation, or decisions concerning issues in which they have a shared interest (by which they are integrated). It involves the division of norms and mutual favourable interaction [97]. The architecture of collaboration is the concept, which correspond particularly well with the practice of establishing public-social partnerships, because it attributes the success achieved by multi-entity organisational undertakings to the selection of actors based on their resources and values ensuring self-organisation. It favours a community within which the actors raise and share resources, while existing protocols and relations allow for the cooperation between numerous actors [98]. All of the elements together create organisational contexts as well as operate within them. These contexts involve different connections of transparency, shared values and norms of mutuality, trust and altruism $[98,99]$. The source of control and coordination is direct interaction between actors, and not hierarchical subordination.

Bringing our considerations to an end, we would like to stress the cognitive value of the study, as it provides information on the operationalisations of management practices in the three management models, while at the same time it reveals the growth potential of public management in partnerships, in particular, following the logic that allows for the adoption of the concepts relating to the architecture of collaboration. The results show that the architecture of collaboration may be of significant importance for the practice of managing partnerships and it contributes to the public value creation, and, as a consequence, advances public management theory by incorporating other researchers' works and supplementing them with new observations. To sum up the issues raised in the paper, we conclude that, in the public sector, managing public programmes aiming to deliver social services through partnerships has become a norm rather than an exception in many EU member states. For public sector organisations, open collaboration is crucial to change the focus of innovation from internal administrative processes towards new services and improved results for society [100]. This is the consequence of the increasingly popular view, which is shared both by practitioners and researchers, that services integrated within a multi-entity collaboration network-due to their lower fragmentation and increased coordination - offer the way to create a more effective system, and, as a result, better outcomes, customers receive higher individual benefits and collaborating organisations grow $[47,101]$. 
Therefore, nowadays, the only way that governments have to deal with complex problems in society (commonly referred to as 'wicked problems') are through the use of collaborative structures that involve other non-state stakeholders [102]. This model of thinking about the architecture of collaboration as a peculiar metaphor of organisation can be referred to the rules inside partnerships, or, in other words, collaboration launched between public and social organisations that aims to create public value, which seems to offer a new and interesting research area.

Author Contributions: Conceptualization, A.F.-W. and M.W.-P.; Methodology, A.F.-W. and M.W.-P.; Writing-original draft, A.F.-W. and M.W.-P.; Writing-review \& editing, A.F.-W. and M.W.-P.

Funding: This research was partly funded by the means of Dean of Faculty of Economics and party by "Motivating employees as an element of HRM in entities providing public services" University of Economics in Katowice statutory research project.

Conflicts of Interest: The authors declare no conflict of interest.

\section{References}

1. Boyne, G.A. Public Choice Theory and Local Government: A Comparative Analysis of the UK and USA; MacMillan: London, UK, 1998.

2. Brown, L.; Osborne, S.P. Risk and Innovation. Towards a Framework for risk governance in public services. Public Manag. Rev. 2013, 16, 186-208. [CrossRef]

3. Mintrom, M.; Luetjens, J. Creating Public Value: Tightening Connections Between Policy Design and Public Management. Policy Stud. J. 2017, 45, 170-190. [CrossRef]

4. Orn-orn, P.; Ting, B. Collaboration Coproduction, Networks-Convergence of Theories. Public Manag. Rev. 2015, 17, 587-614.

5. Osborne, S.P.; McLaughlin, K.; Chew, C. Relationship marketing, relational capital and the governance of public services delivery. In The New Public Governance: Emerging Perspectives on the Theory and Practice of Public Governance; Osborne, S.P., Ed.; Routledge: New York, NY, USA, 2012; pp. 35-42.

6. Osborne, S.P.; Radnor, Z.; Strokosch, K. Co-production and the co-creation of value in public services: A suitable case for treatment? Public Manag. Rev. 2016, 18, 639-653. [CrossRef]

7. Osborne, S.P.; Strokosch, K. It takes two to tango? Understanding the co-production of public services by integrating the services management and public administration perspectives. Br. J. Manag. 2013, 24, 31-47. [CrossRef]

8. Ostrom, E. Governing the Commons. The Evolution of Institutions for Collective Action; Cambridge University Press: Cambridge, UK, 1990.

9. Jordan, T. Activism! Direct Action, Hactivism and the Future of Society; Reaktion Books: London, UK, 2004.

10. Wronka-Pośpiech, M.; Frączkiewicz-Wronka, A. The use of ICT for achieving the objectives of the business model-Social enterprise perspective. Pol. J. Manag. 2014, 10, 33-42.

11. Hilgers, D.; Ihl, C. Citizensourcing: Applying the Concept of Open Innovation to the Public Sector. Int. J. Public Particip. 2010, 67, 72-73.

12. Bossink, B.A. The Development of Co-Innovation Strategies: Stages and Interaction Patterns in Interfirm Innovation. RD Manag. 2002, 32, 311-320. [CrossRef]

13. Bonney, L.; Clark, R.; Collins, R.; Fearne, A. From Serendipity to Sustainable Competitive Advantage: Insights from Houston's Farm and their Journey of Co-Innovation. Supply Chain Manag. 2007, 12, 395-399. [CrossRef]

14. Lee, S.M.; Olson, D.L.; Trimi, S. Co-Innovation: Convergenomics, Collaboration, and Co-Creation for Organizational Values. Manag. Decis. 2012, 50, 817-831. [CrossRef]

15. Odenthal, S.; Tovstiga, G.; Tambe, H.; van Oene, F. Co-Innovation: Capturing the Innovation Premium for Growth. Prism 2004, 1, 41-55.

16. Van Blokland, W.W.A.B.; Verhagen, W.J.; Santema, S.C. The Effects of Co-Innovation on the Value-Time Curve: Quantitative Study on Product Level. J. Bus. Mark. Manag. 2008, 2, 5-24. [CrossRef]

17. Bitzer, V.; Bijman, J. From innovation to co-innovation? An exploration of African agrifood chains. Br. Food J. 2015, 117, 2182-2199. [CrossRef] 
18. Romero, D.; Molina, A. Collaborative networked organisations and customer communities: Value co-creation and co-innovation in the networking era. Prod. Plan. Control 2011, 22, 447-472. [CrossRef]

19. Prahalad, C.K.; Ramaswamy, V. Co-Creation Experiences: The Next Practice in Value Creation. J. Interact. Mark. 2004, 18, 5-14. [CrossRef]

20. Ramaswamy, V.; Gouillart, F. Building the Co-Creative Enterprise. Harv. Bus. Rev. 2010, 88, 100-109.

21. Von Hippel, E.; Ozawa, S.; De Jong, J.P.J. The age of the consumer-innovator. MIT Sloan Manag. Rev. 2011, 53, 27-35.

22. Westerlund, M.; Rajala, R. Learning and Innovation in Inter-Organizational Network Collaboration. J. Bus. Ind. Mark. 2010, 25, 435-442. [CrossRef]

23. Löfgren, A. International Network Management for the Purpose of Host Market Expansion: The Mediating Effect of Co-Innovation. J. Int. Entrep. 2014, 12, 162-182. [CrossRef]

24. Parmentier, G.; Mangematin, V. Orchestrating Innovation with User Communities in the Creative Industries. Technol. Forecast. Soc. Chang. 2004, 83, 40-53. [CrossRef]

25. Xu, Q.; Wanyan, S.; Yang, H.; Chen, J. Managing co-innovation: An effect way to reinforce competence. In Proceedings of the Annual Meeting for the Engineering Management Society, Albuquerque, NM, USA, 15 August 2000; pp. 563-567. [CrossRef]

26. Dinesen, B.; Seemann, J.; Gustafsson, J. Development of a Program for Tele-Rehabilitation of COPD Patients Across Sectors: Co-Innovation in a Network. Int. J. Integr. Care 2011, 11, e012. [CrossRef] [PubMed]

27. Bourgon, J. A New Synthesis of Public Administration: Serving in the 21st Century; School of Policy Studies and McGill-Queen's University Press: Kingston, ON, USA, 2011.

28. Mulgan, G.; Albury, D. Innovation in the Public Sector; Cabinet Office Strategy Unit: London, UK, 2003; Available online: www.childrencount.org/documents/Mulgan\%20on\%20Innovation.pdf (accessed on 19 May 2018).

29. Bason, C. Leading Public Sector Innovation: Co-Creating for a Better Society; The Policy Press: Portland, OR, USA, 2010.

30. European Commission. Powering European Public Sector Innovation: Towards a New Architecture; Report of the Expert Group on Public Sector Innovation; European Commission: Brussels, Belgium, 2013.

31. Borys, B.; Jemison, D.B. Hybrid arrangements as strategic alliances: Theoretical issues in organizational combinations. Acad. Manag. Rev. 1989, 14, 234-249. [CrossRef]

32. Moore, M.H. Creating Public Value Strategic Management in Government; Harvard University Press: Cambridge, MA, USA, 1995.

33. Moura e Sá, P.; Paco, A.; Alves, H.; Manuel, M.; Leitão, M. Integration and Co-creation for Better Public Services: A Case Study Based on The Portugese Citizens. In Proceedings of the IRSPM 2015 Conference, Birmingham, UK, 30 March-1 April 2015.

34. Gouillart, F.; Hallett, T. Co-Creation in Government. Stanf. Soc. Innov. Rev. 2015, 13, 40-47.

35. Cepiku, D.; Giordano, F. Co-Production in Developing Countries: Insights from the community health workers experience. Public Manag. Rev. 2014, 16, 317-340. [CrossRef]

36. Van Eijka, C.J.A.; Steena, T.P.S. Why People Co-Produce: Analysing citizens' perceptions on co-planning engagement in health care services. Public Manag. Rev. 2014, 16, 358-382. [CrossRef]

37. Virtanen, P.; Stenvall, J. The evolution of public services from co-production to co-creation and beyond: New Public Management's unfinished trajectory? Int. J. Leadersh. Public Serv. 2014, 10, 91-107. [CrossRef]

38. Agarwal, R.; Selen, W. Dynamic capability building in service value networks for achieving service innovation. Decis. Sci. 2009, 40, 431-475. [CrossRef]

39. Rodger, J.J. From a Welfare State to a Welfare Society; Palgrave Macmillan: London, UK, 2000.

40. Van Berkel, R.; Borghi, V. New Modes of Governance in Activation Policies. Int. J. Sociol. Soc. Policy 2007, 27, 277-286. [CrossRef]

41. Van Berkel, R.; Hornemann Møller, I. Active Social Policies in the EU; Policy Press at the University of Bristol: Bristol, UK, 2002.

42. Lægreid, P.; Rykkja, L.H. Hybrid Collaborative Arrangements: The Welfare Administration Reform in Norway Between Hierarchy and Network. Public Manag. Rev. 2015, 17, 960-980. [CrossRef]

43. Binder, M.; Clegg, B. Enterprise management: A new frontier for organizations. Int. J. Prod. Econ. 2007, 106, 409-430. [CrossRef] 
44. Aneesh, Z.; Moniz, A. Importance of Global Co-Innovation Networks: A TCS Case Study; IET Working Papers Series; IET: Stevenage, UK, 2009; Volume 1, pp. 1-23.

45. Janerose, N.; de Coster, R. Co-Innovation: The Future of Telemedicine in Developing Countries. In Proceedings of the Annual Meeting for the Society of British Academy of Management (BAM) Doctoral Symposium, Belfast, UK, 8 September 2014.

46. Feller, J.; Finnegan, P.; Nilsson, O. Open innovation and public administration: Transformational typologies and business model impacts. Eur. J. Inf. Syst. 2011, 20, 358-374. [CrossRef]

47. Pestoff, V. Collective Action and the Sustainability of Co-Production. Public Manag. Rev. 2014, 16, $383-401$. [CrossRef]

48. Alford, J. The Multiple facets of Co-Production: Building on the work of Elinor Ostrom. Public Manag. Rev. 2014, 16, 299-316. [CrossRef]

49. Araujo, L.; Brito, C. Agency and Constitutional Ordering in Networks. Int. Stud. Manag. Organ. 1998, 27, 22-46. [CrossRef]

50. Niemczyk, J.; Stańczyk-Hugiet, E.; Jasiński, B.M.; Chrisidu-Budnik, A. Sieci Międzyorganizacyjne. Wspótczesne Wyzwanie dla teorii i Praktyki Zarzadzania (Inter-Organizational Networks. A Contemporary Challenge for Management Theory and Practice); C.H. Beck: Warszawa, Poland, 2012.

51. Chisholm, R.F. On the Meaning of Networks. Group Organ. Manag. 1996, 21, 216-236. [CrossRef]

52. Halligan, J. Coordination of Welfare Through a Large Integrated Organization: The Australian department of human services. Public Manag. Rev. 2015, 17, 1002-1020. [CrossRef]

53. Kożuch, B. Skuteczne Wspótdziałanie Organizacji Publicznych i Pozarządowych (Effective Cooperation of Public and Non-Governmental Organizations); Monografie i Studia Instytutu Spraw Publicznych Uniwersytet Jagielloński: Kraków, Poland, 2011.

54. Fjeldstad, Ø.D.; Snow, C.; Miles, R.E.; Letti, C. The Architecture of Collaboration. Strateg. Manag. J. 2012, 33, 734-750. [CrossRef]

55. Simon, H.A. The structure of ill-structured problems. Artificial Intelligence. Strateg. Manag. J. 1973, 14, 131-142. [CrossRef]

56. Thompson, J.D. Organizations in Action; McGraw-Hill: New York, NY, USA, 1967.

57. Christensen, C.M. The Innovator's Dilemma: When New Technologies Cause Great Firms to Fail; Harvard Business School Press: Boston, MA, USA, 1997.

58. Christensen, C.M.; Bower, J.L. Customer power, strategic investment, and the failure of leading firms. Strateg. Manag. J. 1996, 17, 197-218. [CrossRef]

59. Geddes, L. In search of collaborative public management. The prolific and other priority offender programme. Public Manag. Rev. 2012, 14, 947-966. [CrossRef]

60. Rainey, H.G.; Chun, Y.H. Public and Private Management Compared. In The Oxford Handbook of Public Management; Ferlie, E., Lynn, L.E., Jr., Pollitt, C., Eds.; Oxford Press: Oxford, UK, 2005; pp. 72-102.

61. Andrews, R.; Entwistle, T. Four faces of public service efficiency. What, how, when and form whom to produce. Public Manag. Rev. 2012, 15, 246-264. [CrossRef]

62. Benyon, J.; Edwards, A. Community Governance of Crime Control. In The New Management of British Local Governance; Stoker, G., Ed.; Macmillan Press: Basingstoke, UK, 1999; pp. 145-167.

63. Bovens, M. Public accountability. In The Oxford Handbook of Public Management; Ferlie, E., Lynn, L.E., Jr., Politt, C., Eds.; Oxford University Press: Oxford, UK, 2005.

64. Knack, S. Social Capital and the Quality of Government: Evidence from the States. Am. J. Polit. Sci. 2002, 46, 772-785. [CrossRef]

65. Blair, S. Public Participation and Community Development: The Role of Strategic Planning. Public Adm. Q. 2004, 28, 102-147.

66. Nash, M. Enter the 'Polibation Officer'. Int. J. Police Sci. Manag. 1999, 1, 360-368. [CrossRef]

67. Blaug, R.; Horner, L.; Lekhi, R. Public Value, Politics and Public Management. A Literature Review; The Work Foundation: London, UK, 2006.

68. Denis, J.L.; Langley, A.; Rouleau, L. Rethinking leadership in public organizations. In The Oxford Handbook of Public Management; Ferlie, E., Lynn, L.E., Jr., Politt, C., Eds.; Oxford University Press: Oxford, UK, 2005; pp. 446-467.

69. Ingraham, P. Striving for Balance: Reforms in human resources management. In The Oxford Handbook of Public Management; Ferlie, E., Lynn, L.E., Jr., Politt, C., Eds.; Oxford University Press: Oxford, UK, 2005. 
70. McGuire, M. Managing networks: Propositions on what managers do and why they do it. Public Adm. Rev. 2002, 62, 599-609. [CrossRef]

71. Burnett, R.; Appleton, C. Joined-up Services to Tackle Youth Crime. A Case Study in England. Br. J. Criminol. 2004, 44, 34-54. [CrossRef]

72. Nutt, P.C. Comparing Public and Private Sector Decision-Making Practices. J. Public Adm. Res. Theory 2006, 16, 289-318. [CrossRef]

73. Provan, K.G.; Kenis, P. Modes of network governance: Structure, management, and effectiveness. J. Public Adm. Res. Theory 2008, 18, 229-252. [CrossRef]

74. Erol, R.; Millie, A. Getting Ready for the PPO Strategy: Managing Prolific and Other Priority Offenders in Birmingham; A Report for the Birmingham Community Safety Partnership; Policy Research Institute: Wolverhampton, UK, 2005.

75. The Audit Commission. Working Better Together? Managing Local Strategic Partnerships; Cross-Cutting National Report 2009; The Audit Commission: London, UK, 2010.

76. Crawford, A. The Local Governance of Crime; Oxford University Press: Oxford, UK, 1999.

77. Proeller, I.; Schedler, K. Change and Continuity in the Continental Tradition of Public Management. In The Oxford Handbook of Public Management; Ferlie, E., Lynn, L.E., Jr., Politt, C., Eds.; Oxford University Press: Oxford, UK, 2005.

78. Murdock, A. Stakeholder Theory, Partnerships and Alliances in the Health Care Sector of the UK and Scotland. Int. Public Manag. Rev. 2004, 5, 21-40.

79. Bryson, J.M. What to do when stakeholders master. Stakeholder identification and Analysis Techniques. Public Manag. Rev. 2004, 6, 22-53. [CrossRef]

80. Pandey, S.K.; Garnett, J.J. Exploring public sector communication performance: Testing a model and drawing implications. Public Adm. Rev. 2006, 66, 37-51. [CrossRef]

81. Dingwall, R.; Strangleman, T. Organizational culture in the public services. In The Oxford Handbook of Public Management; Ferlie, E., Lynn, L.E., Jr., Politt, C., Eds.; Oxford University Press: Oxford, UK, 2005.

82. Frączkiewicz-Wronka, A. Zarzadzanie Usługami Społecznymi. Studium Partnerstw Publiczno-Społecznych (Management of Social Services. Study of Public-Social Partnerships); Diffin: Warszawa, Poland, 2014.

83. Anfara, V.A.; Mertz, N.T. Theoretical Frameworks in Qualitative Research; Sage: London, UK, 2006.

84. Stake, R.E. Qualitative case studies. In The Sage Handbook of Qualitative Research; Denzin, N.K., Lincoln, Y.S., Eds.; Sage: Thousand Oaks, CA, USA, 2005; pp. 443-466.

85. Van de Ven, A.H. Engaged Scholarship: A Guide for Organizational and Social Research; Oxford University Press: Oxford, UK, 2013.

86. Dempsey, S.E.; Barge, J.K. Engaged Scholarship and Democracy. In Handbook of Organizational Communication: Advances in Theory, Research, and Methods; Mumby, D.K., Putnam, L.L., Eds.; Sage: Thousand Oaks, CA, USA, 2013; pp. 665-688.

87. Eisenhardt, K.M. Building Theories from Case Study Research. Acad. Manag. Rev. 1989, 14, 532-550. [CrossRef]

88. Yin, R.K. Case-Study Research. Design and Methods, 3rd ed.; Sage: London, UK, 2003.

89. Ragin, C. Turning the Tables: How Case Orientated Research Challenges Variable Orientated Research. In Rethinking Social Inquiry Diverse Tools, Shared Standards; Collier, D., Brady, H., Eds.; Rowman and Littlefield: Lanham, MD, USA, 2004.

90. Gatnar, E.; Walesiak, M. Metody Statystycznej Analizy Wielowymiarowej w Badaniach Marketingowych (Methods of Statistical Multidimensional Analysis in Marketing Research); Wydawnictwo AE im. Oskara Langego we Wrocławiu: Wrocław, Poland, 2004.

91. Aldenderfer, M.S.; Blashfield, R.K. Cluster Analysis; Sage Publications: Beverly Hills, CA, USA, 1984.

92. Caliński, T.; Harabasz, J. A Dendrite Method for Cluster Analysis. Commun. Stat. 1974, 3, 1-27.

93. Frączkiewicz-Wronka, A.; Austen, A. Menadżerowie w organizacjach publicznych—W kierunku zwiększania zatrudnialności [Managers in Public Organizations: Improving Employability]. Zarzadzanie Zasobami Ludzkimi 2015, 3-4, 27-41.

94. Adler, P.; Heckscher, C.; Prusak, L. Building a Collaborative Enterprise: Four keys to creating a culture of trust and teamwork. Harv. Bus. Rev. 2011, 89, 95-101.

95. Wood, D.J.; Gray, B. Toward a comprehensive theory of collaboration. J. Appl. Behav. Sci. 1991, 27, $139-162$. [CrossRef] 
96. Ostrom, E. A Behavioral Approach to the Rational Choice Theory of Collective Action. Am. Polit. Sci. Rev. 1998, 92, 1-22. [CrossRef]

97. Wynen, J.; Verhoesta, K.; Ongaro, E.; van Thiel, S. Innovation-Oriented Culture in the Public Sector: Do managerial autonomy and result control lead to innovation? Public Manag. Rev. 2014, 16, 45-66. [CrossRef]

98. Collm, A.; Schedler, K. Strategies for Introducing Organizational Innovation to Public Service Organizations. Public Manag. Rev. 2014, 16, 140-161. [CrossRef]

99. Barney, J.B.; Hansen, M.H. Trustworthiness as a source of competitive advantage. Strateg. Manag. J. 1994, 15, 175-190. [CrossRef]

100. Carstensen, H.V.; Bason, C. Powering Collaborative Innovation: Can Innovations Labs Help? Innov. J. 2012, 17, 1-26.

101. Radnor, Z.; Osborne, S.P.; Kinder, T.; Mutton, J. Operationalizing Co-Production in Public Services Delivery: The contribution of service blueprinting. Public Manag. Rev. 2014, 16, 402-423. [CrossRef]

102. O'Toole, L.J. Treating networks seriously: Practical and Researched-based agendas in public administration. Public Adm. Rev. 1997, 57, 45-52. [CrossRef]

(C) 2018 by the authors. Licensee MDPI, Basel, Switzerland. This article is an open access article distributed under the terms and conditions of the Creative Commons Attribution (CC BY) license (http:/ / creativecommons.org/licenses/by/4.0/). 